\title{
PROSES COMMUNITY DEVELOPMENT PADA PROGRAM KAMPUNG IKLIM DI DESA CUPANG KECAMATAN GEMPOL KABUPATEN CIREBON (STUDI KASUS PROGRAM BANK SAMPAH DALAM PROGRAM KAMPUNG IKLIM)
}

\author{
OLEH \\ REZA RINALDY ${ }^{1}$,SONI A. NULHAQIM, ${ }^{2}$, ARIE SURYA GUTAMA, ${ }^{3}$ \\ ${ }^{1}$ Alumni Program Studi Kesejahteraan Sosial, Fakultas Ilmu Sosial dan Ilmu Politik, Universitas Padjadjaran, \\ rezarinaldy94@gmail.com \\ ${ }^{2}$ Dosen Departemen Kesejahteraan Sosial, Fakultas Ilmu Sosial dan Ilmu Politik, Universitas Padjadjaran, \\ soni.nulhaqim@unpad.ac.id
}

${ }^{3}$ Dosen Departemen Kesejahteraan Sosial, Fakultas Ilmu Sosial dan Ilmu Politik, Universitas Padjadjaran, arie@unpad.ac.id

\begin{abstract}
ABSTRAK
Penelitian ini bertujuan mendeskripsikan proses community development yang terdiri tahapan engagement, assessment, perencanaan program, pemformulasian rencana aksi, implementasi, evaluasi dan hasil perubahan, dan tahapan terminasi. Proses Community Development yang dilakukan di Desa Cupang melalui program bank sampah dari kegiatan CSR PT.Indocement.Metode penelitian yang digunakan adalah jenis deskriptif dengan pendekatan kualitatif, dan teknik penelitian studi kasus. Teknik pengumpulan data meliputi wawancara mendalam, observasi non partisipasi, studi kepustakaan dan studi dokumentasi. Penelitian ini melibatkan 7 Informan yang terdiri dari, staff divisi CSR Indocement, kelompok pengelolaan sampah, aparat pemerintah Desa Cupang dan masyarakat Desa Cupang yang terlibat langsung dalam program bank sampah. Penentuan informan dilakukan berdasarkan tujuan penelitian untuk menggali lebih dalam mengenai community development pada program bank sampah di Desa Cupang.

Hasil dari penelitian ini menunjukan proses community development pada 7 tahapan yang dilakukan hanya ada 5 tahapan yang sudah berjalan sebagaimana mestinya, yaitu tahapan engagement, assessment, perencanaan program, Implementasi, dan terminasi. Adapun tahapan evaluasi belum dilakukan secara menyeluruh dan berkesinambungan. Temuan lain dalam penelitian ini menunjukkan kendala pada pemasaran produk dan manajemen organisasi terutama terhadap sumber daya manusia (SDM) dalam pelaksanaan kegiatan. Dengan demikian, Peneliti memberikan saran agar dilakukan evaluasi secara menyeluruh pada peningkatan kapasitas kelompok pengelolaan sampah dalam bentuk kegiatan Workhshop "Manajemen Organisasi" untuk meningkatkan pengetahuan dan pemahaman terkait dalam manajemen organisasi pada anggota kelompok pengelolaan sampah.
\end{abstract}

Kata Kunci : Community Development, CSR, Kelompok Pengelolaan Sampah".

\section{ABSTRACT}

This thesis aims to describe the community development process that consists of several phases; engagement, assessment, program planning, action plan formulation, implementation, evaluation and changes results, and termination. Community development process is necessary to be described because PT Indocement's CSR initiator said that if this process can be described well, it is impossible for waste bank of community development conducted in Cupang village can be adopted by PT Indocement's 
CSR.Method used in this research is descriptive method along with qualitative approach and descriptive technique. Meanwhile, data collection techniques used in this research are in-depth interviews, nonparticipation observation, literature study, and documentation study. The informants involved in this research are seven people; one of CSR region coordinator, one of waste bank program coordinator of Indocement's CSR, one of head of the waste management group, two of member of the waste management group, one of Cupang's village officials, and one of Cupang village's citizen who directly involved in the waste bank program.

The result of this research indicates that, instead of seven, there are five phases of community development process that are already running. Those phases are engagement, assessment, program planning, implementation, and termination. Meanwhile, the evaluation process has not been done either comprehensively nor sustainable. The other finding in this research shows the obstacles of product marketing and organizational management in the process, especially human resources (SDM). This company used to have 30 member of waste management group but now it was cut to 6 active members, so it hampers the implementation and lowers the service to the community.

Keywords: community development process, PT Indocement Tbk CSR, waste management group, "Manajemen Organisasi" workshop.

\section{PENDAHULUAN}

Sampah menjadi salah satu pendorong perubahan iklim termasuk pada isu GRK, volume sampah di Indonesia sekitar 1 juta meter kubik perhari, namun baru $42 \%$ di antaranya yang terangkut dan diolah dengan baik. Sampah menjadi masalah penting di Indonesia (www.tempo.co.com diakses pada 20/03/2016)

Kerusakan lingkungan yang terjadi khususnya dalam lingkup sampah pemerintah mengeluarkan peraturan pemerintah terkait pengelolaan sampah PP No.18 Tahun 2012 sebagai peraturan pelaksanaan UU No 18 Tahun 2008 tentang pengelolaan sampah rumah tangga dan sampah sejenis sampah rumah tangga. Kementrian Lingkungan Hidup dan Kehutanan (KLHK) untuk merespon perubahan iklim melalui Peraturan Menteri Lingkungan Hidup Nomor 19 Tahun 2012 menggagas Program Kampung Iklim. Aksi adaptasi dan mitigasi salah satunya Pengelolaan dan pemanfaatan sampah/limbah (www.menlh.go.id.com diakses : 16/03/2016).

Program kampung iklim ini salah satunya dilakukan di Desa Cupang sebagai salah satu program tanggung jawab sosial perusahaan PT. Indocement Tunggal Prakarsa, Palimana. Dengan menggunakan metode community development (pengembangan masyarakat) sebagai pendekatan atau strategi dalam tanggung jawab sosial perusahaan (corporate social responsibility) (Suharto, 2006).

Pengembangan masyarakat ini bertujuan untuk memberdayakan masyarakat yang dilakukan melalui usaha-usaha yang terorganisir untuk memperbaiki kondisi kehidupan masyarakat, serta meningkatkan kemampuan masyarakat melalui integritas dan kemandirian sehingga lebih bernuansa pembangunan berkelanjutan (Dunham, 1960 : 33-35). Sehingga metode pengembangan masyarakat menjadi metode yang sesuai dilakukan dalam program kampung iklim. 
Program kampung iklim yang di laksanakan di Desa Cupang Kecamatan Gempol Kabupaten Cirebon bersama CSR PT.Indocement didasarkan kepada kondisi wilayah dan potensi masyarakat juga menjadi alasan Desa Cupang melaksanakan program kampung iklim. Kondisi wilayah yang gersang akibat eksploitasi alam yang ada membuat rentan terhadap perubahan iklim.

Program Kampung Iklim di Desa Cupang sudah berlangsung sejak April 2013 dan di mulai sejak tahun 2014 dengan lingkup adaptasi dan mitigasi perubahan iklim, aksi yang dilakukan dalam program kampung iklim Desa Cupang terkait aksi mitigasi yang dilakukan adalah pengendalian sampah yang dilakukan oleh kelompok pengelola sampah.

Penelitian mengkaji tahapan community development pada program bank sampah sebagai bagian dari program kampung iklim, program bank sampah dirasakan menarik karena menjadi percontohan untuk bank sampah Kabupaten Cirebon dan program bank sampah juga sebagai penggerak awal dari program-program lingkungan lainnya dan berkontribusi menjuarai aplikasi program kampung iklim.

\section{PERMASALAHAN}

Berdasarkan latar belakang yang dikemukakan diatas, maka rumusan masalah dari penelitian ini yaitu sebagai berikut :

1. Bagaimana tahapan Engagementdalam Program Bank Sampah di Desa Cupang?

2. Bagaimana tahapan Assessmentdalam Program Bank Sampah di Desa Cupang ?

3. Bagaimana tahapan Perencanaan Alternatifdalam Program Bank Sampah di Desa Cupang?

4. Bagaimana tahapanPemformulasian Rencana Aksi dalam Program Bank Sampah di Desa Cupang?
5. Bagaimana tahapan Implementasidalam Program Bank Sampah di Desa Cupang?

\section{METODE}

Metode penelitian yang digunakan dalam penelitian ini adalah jenis deskriptif dengan pendekatan kualitatif dan teknik studi kasus. Teknik pengumpulan data yang digunakan adalah wawancara mendalam, observasi nonpartisipasi, studi kepustakaan dan studi dokumentasi. Teknik pengolahan data yang digunakan adalah reduksi data, penyajian data (display data), dan penarikan kesimpulan. Penelitian ini melibatkan tujuh informan, yang terdiri dari, 2 orang staff divis CSR Indocement Pabrik Palimanan, 3 orang kelompok pengelolaan sampah, 1 orang aparat pemerintahan Desa Cupang dan 1 orang masyarakat Desa Cupang. Penentuan informan dilakukan berdasarkan tujuan penelitian untuk menggali lebih dalam mengenai proses community development pada program bank sampah di Desa Cupang.

\section{HASIL PENELITIAN DAN PEMBAHASAN}

Desa Cupang merupakan desa yang terletak di Kabupaten Cirebon, Kecamatan Gempol. dengan mempunyai luas wilayah \pm 193 Ha dengan luas wilayah pemukiman itu sendiri seluas 26,385 Ha dengan sebagian besar luas wilayah adalah lahan pertanian.

Jumlah penduduk Desa Cupang pada tahun 2016 berjumlah 3.828 orang dengan jumlah kepala keluarga (KK) adalah sebesar 1.226 orang dengan mata pencaharian yang paling banyak adalah petani.

Program kampung iklim berlingkup nasional yang dikembangkan Kementerian Lingkungan Hidup (KLH) untuk mendorong partisipasi aktif masyarakat dan seluruh pihak dalam melaksanakan aksi lokal untuk 
meningkatkan ketahanan terhadap dampak perubahan iklim dan pengurangan emisi GRK (Gas Rumah Kaca). berkontribusi kepada upaya pembangunan nasional.

Program bank sampah ini dilakukan di Desa Cupang yang bermitra dengan Indocement pabrik palimanan melalui divisi CSRnya sebagai bentuk pengembangan masyarakat yang dilakukan kepada desa binaanya.

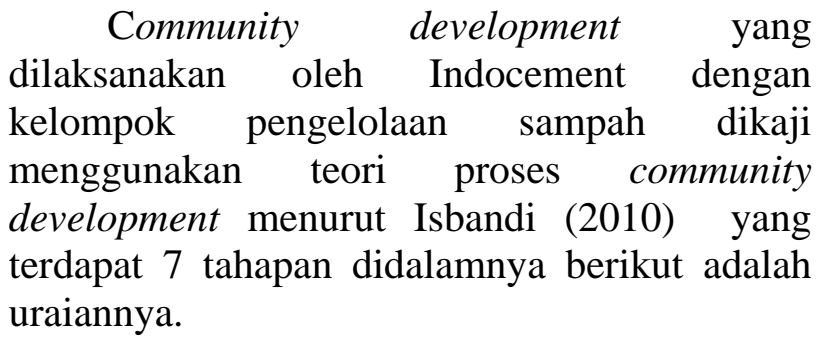

\section{Tahapan Enggagement}

Tahapan Engagement merupakan proses pendekatan paling awal yang dilakukan dalam pengembangan masyarakat. Pendekatan ini berbicara mengenai persiapan baik didalam persiapan petugas terkait dengan kapabilitas dan kesediaan petugas kemudian persiapan lapangan dalam meninjau kecocokan lapangan yang sesuai dengan tujuan kemudian melakukan pendekatan awal kepada sasaran kelompok masyarakat di Desa Cupang sehingga dapat meningkatkan keberdayaannya.

a. Persiapan petugas

Pada awal tahun 2012 Indocement Pabrik Palimanan terdorong dalam melakukan program untuk mengurangi atau menguraikan sampah khususnya kepada desa binaan.

Program bank sampah disosialisasikan melalui beberapa pertimbangan antar pertugas, sehingga diputuskan dilakukan di Desa Cupang sebagai desa percontohan. b. Persiapan lapangan

Persiapan lapangan dilakukan dengan melihat kondisi dan kecocokan tempat sasaran. Permasalahan sampah di Desa Cupang yang cukup ditemui beberapa permasalahan sampah yang berbahaya seperti penimpunan, penguraian dengan pembakaran dan jumlah yang meningkat.

Pada akhir tahun 2012 mulailah disosialisasikannya program bank sampah oleh petugas kepada kelompok Jamaah Al-Karimah yang berada di Dusun Desa di RW 06 karena dengan melihat keaktifan mereka. Ibu-ibu Kelompok Jamaah Al-Karimah pun tertarik akan adanya program ini, sehingga disana sudah adanya kecocokan.

Tidak adanya kesepakatan mengenai waktu. Namun, adanya batasan waktu yang dibuat petugas untuk mengoptimalkan program.

\section{Tahapan Assessment}

Tahapan assessment ini merupakan proses mengindentifikasian berbagai masalah dan kebutuhan serta potensi yang ada di masyarakat Desa Cupang..

a. Perumusan kebutuhan dan masalah masyarakat

Perumusan dilakukan petugas bersama masyarakat dengan pola Komunikasi melalui BILIKOM (BIna LIngkungan dan KOMunikasi) yaitu terdiri dari tokoh masyarakat, RT atau RW yang ada dimasyarakat. Bilikom ini berfungsi sebagai sarana komunikasi antara Indocement dengan Desa Cupang.

Didalam proses komunikasi dan diskusi selalu melibatkan masyarakat selaras dengan penuturan Diana Conyers dalam Susetiawan (1994: 154-155) pentingnya partisipasi salah satunya, bahwa masyarakat akan lebih mempercayai program pembangunan jika dilibatkan dalam proses persiapan dan 
perencanaanya. Namun, terkadang masyarakat tidak cepat merespon informasi yang ada karena itu disini peran petugas.

masalah yang didapatkan dari proses identifikasi diantaranya penimbunan sampah di lingkungan. Sampah rumah tangga banyak berserakan dan menggunung. Dan belum adanya kesadaran pemahaman tentang menjaga lingkungan dengan baik terutama terkait masalah sampah yang memang kerap dianggap sepele.

Masalah lain adalah belum ada wadah untuk dapat melaksanakan permasalahan sampah ini seperti kelompok bergerak dibidang lingkungan.

\section{b. Pengidentifikasian potensi masyarakat}

Potensi-potensi yang didapat yaitu kesadaran yang mulai timbul, kesadaran akan memilah-milih sampah. Masyarakat sudah tidak menggunakan lubang sampah lagi untuk menampung sampah digantikan oleh tong sampah dan karung sampah sebagai penampungan sampah. Potensi lain bahwa terdapat banyak kelompok masyarakat di Desa Cupang seperti Kelompok PKK, dan Kelompok Ibu-ibu Jamaah Pengajian yang aktif. Menjadi potensi besar untuk dapat menjalankan kelompok pengelola sampah. Potensi selanjutnya terkait pada angka partisipasi yang tinggi terkait dengan adanya suatu kegiatankegiatan yang diadakan.

\section{c. Penilaian kebutuhan dan masalah masyarakat \\ Pembentukan Kelompok dijadikan} kebutuhan yang harus segera dibentuk didalam pengelolaan sampah. Sehingga dengan bantuan petugas dibentuklah kelompok bank sampah yang berasal dari kelompok ibu-ibu jamaah AlKarimah tahun 2013.
Struktur organisasi dari kelompok pengelolaan sampah itu sendiri terdiri dari Ketua kelompok, Sekretaris, Bendahara, Seksi Kerajinan, Seksi Penimbangan, Seksi Transportasi dan Penjualan, dan Seksi Dokumentasi.

Anggota kelompok pengelolaan sampah juga selain terlibat didalam organisasi kelompok pengelolaan sampah tapi aktif di keorganisasian masyarakat lainnya.

\section{Tahapan Perencanaan Program}

Tahapan perencanaan program terkait kegiatan apa saja yang tepat dilaksanakan dengan menggunakan metode musyawarah. Perencanaan program ini dapat berisi metode dan strategi. Dalam proses perencanaan program ini juga ditentukannya tolak ukur keberhasilan program.

a. Perumusan alternatif kegiatan dalam penyelesaian masalah

Perencanaan yang dibuat kelompok pengelolaan sampah bersama petugas. Terkait pada kapabilitas SDM terkait pengetahuan dan keterampilan khususnya terkait dengan pengelolaan sampah ramah lingkungan. Perencanaanpenyebaran informasi dan penyadaran masyarakat. Hal ini untuk meningkatkan partispasi masyarakat didalam mengikuti program bank sampah.

b. Perumusan metode dan strategi program

Metode dan strategi pelatihaan untuk meningkatkan kapabilitas SDM kelompok pengelolaan sampah. Setiap pelatihan yang dilakukan oleh tenaga yang profesional di bidang pelatihan yang ingin diberikan. Petugas sendiri hanya mengkordinasikan.

Metode dan strategi penyebaran informasi terkait adanya program bank sampah. Strategi yang digunakan aparat desa melalui setiap perangkatRTnya. Kemudian kelompok 
pengelolaan sampah melalui jamaah pengajian disetiap RTnya.Serta mengundang masyarakatuntuk menghadiri acara sosialisasi sekaligus diskusi terkait dengan program bank sampah di balai desa. Strategi penyadaran yaitu dengan percontohan yang dilakukan oleh kelompok pengelolaan sampah dan pembuatan film tentang pengelolaan sampah.Metode strategi selanjutnya untuk mempermudah partisipasi masyarakat adalah tidak adanya persyaratan khusus untuk mengikuti program bank sampah. Staregi menarik masyarakat dengan mengikutkan masyarakat dalam pelatihan.

\section{c. Perumusan tolak ukur keberhasilan}

Dalam memaksimalkan program bank sampah dibuatlah tolak ukur bahwa program bank sampah ini dikatakan berhasil. Kelompok pengelolaan sampahbersama dengan petugas menentukan tujuan program bank sampah yang menjadi tolak ukur keberhasilan program bank sampah.Tujuan ini ada Adapun tujuannya terbagi menjadi tujuan umum dan tujuan khusus, yang berisi sebagai berikut :

Tujuan Umum

Menciptakan lingkungan desa yang asri dari pencemaran sampah rumah tangga

Tujuan Khusus

1) Mewujudkan kelompok pengelolaan limbah sampah desa di tiap-tiap blok

2) Mewujudkan sistem pengelolaan limbah sampah desa yang baik

3) Mewujudkan pemanfaatan sampah menjadi barang yang berdaya jual

4) Membuka lapangan kerja bagi masyarakat desa cupang
5) Mewujudkan peningkatan penghasilan masyarakat

6) Menciptakan ciri khas desa cupang yang asri

\section{Tahapan Pemformulasian Rencana Aksi}

Proses selanjutnya yang dilakukan adalah tahapan pemformulasian rencana aksi. Disini Petugas membantu menentukan skala prioritas terkait kegiatan mana yang harus dilakukan terlebih dahulu. Dan juga merumuskan terkait dengan gagasan-gagasan kelompok pengelolaan sampah terkait program bank sampah dalam bentuk tertulis (proposal).

a. Penetepan prioritas rencana aksi

Tidak adanya penentuan atau penilaian mana yang sebaiknya dilakukan terlebih dahulu. hal ini lebih terkait dengan kebutuhan apa saja yang harus dilaksanakan terlebih dahulu. Hal yang utama yang mereka lakukan adalah kegiatan-kegiatan pelatihan sebagai modal pelaksanaan kelompok melakukan pengelolaan sampah.

b. Pembuatan permintaan bantuan (proposal)

Proses pembuatan proposal awalnya dibuatkan oleh petugas tetapi kini dibuat sendiri oleh pihak kelompok pengelola sampah. Walaupun, begitu tetapi isi didalam proposal itu sendiri didiskusikan bersama antara kelompok pengelolaan sampah dengan petugas.

Proposal isinya terkait hal-hal yang sekiranya untuk menunjang program bank sampah itu sendiri disampaikan baik oleh kelompok pengelolaan sampah atau petugas. 


\section{Tahapan Implementasi}

Tahapan implementasi program lebih kepada kegiatan yang disesuiakan dengan perencanaan yang sebelumnya disepakati bersama yaitu kegiatan pelatihan, penyebaran informasi, penyadaran masyarakat. Pelaksanaan program bank sampah terkait dengan pengolahan sampah. Hal-hal yang terkait dengan bantuan yang didapatpun dilihat dalam tahapan implementasi ni.

\section{a. Tahapan pelaksanaan program}

Pelaksanaan program diawali pelatihan. Pelatihan yang diberikan adalah pelatihan kerajinan, pemilahan, pelatihan pemasaran dan pelatihan lainnya yang berhubungan terkait program bank sampah.Dalam pelatihan kerajinan memfokuskan pada pemanfaatansampah plasticmenjadi kerajinan.Pelatihan itu sendiri diadakan di balai desa pada bulan April-Juni 2013.

Penyebaran informasi diberikan kepada ibu-ibu pada acara di balai desa dilakukan sebanyak 3 kali adanya pada bulan Februari 2013 dengan jumlah 100 orang yang datang. Penyebaran informasi selain itu dilakukan melalui aparat desa dan petugas. Sedangkan penyadaran dengan melakukannya melalui percontohan dan media film. Film ini bermuatan informasi mengenai pengelolaan sampah.

Proses pembayaran sampah kepada masyarakat diberikan 2 pilihan yaitu bayar langsung atau ditabung, Proses pencatatan yang dilakukan sangat manual dan tradisional karena terkendala dengan pengetahuan teknologi.

Proses pengambilan sampah ke rumah anggota bank sampah itu sendiri biasanya dilakukan seminggu sekali, namun tidak bisa tentukan. Hal ini dikarenakan kesibukan anggota kelompok pengelolaan sampah.penjualan sampah itu sendiri, adanya perbedaan pendapatan yang didapat dari sampah keluarga dengan sampah yang dihasilkan dari usaha yang tentunya lebih besar. Permasalah juga ditemukan dalam pelaksanaan diantaranya masalah pertama adalah terkait pada informasi, keterlambatan informasi didalam penjualan sampah membuat kelompok pengelolaan sampah kerap mengalami kerugian. Kurangnya pengoptimalaan penjualan kerajinan karena tidak di lakukan besar-besaran dan juga tidak ada target pasar.

Pada tahun pertama tepatnya 2013 anggota bank sampah berkisar sekitar 40-50 anggota. Setelah berjalan sekitar 3 tahun lamanya atau sampai tahun 2016. Jumlah dari anggota bank sampah itu sendiri sudah mencapai 160 orang yang tercatat di pembukuan anggota bank sampah (ditabung) tapi untuk seluruhnya ada sekitar 200 orang lebih. Namun, justru terjadi penurunan anggota kelompok pengelolaan sampah awalnya berjumlah puluhan orang yang menjadi kini hanya 5-6 orang saja yang terdiri dari 5 wanita dan 1 pria yang aktif.

\section{b. Pengawasan dan pendampingan}

Proses pendampingan dan pengawasan yang dilakukan oleh petugas tidak hanya dilakukan selama pelaksanaan berlangsung tetapi sudah dilakukan sejak awal program berlangsung. Petugas mendatangi kelompok pengelolaan sampah untuk bertemu dan berdiskusi. sesuai dengan pendapat Adicondro (1990) yaitu Fasilitator harus bekerjasama dengan masyarakat dan bukannya bekerja untuk masyarakat.

Pendampingan yang dilakukan oleh petugas yaitu dengan terus adanya komunikasi yang baik dengan kelompok pengelolaan sampah. Pengawasan yang dilakukan oleh petugas dengan metode pengawasan dalam bentuk langsung dengan melihat kondisi-kondisi lingkungan yang ada di Desa Cupang dantidak langsung adalah berupa data yaitu log control 
yang menjadi lingkup kewenangan untuk pengumpulannya oleh kordinator program.

\section{c. Pemberian bantuan}

Bantuan disini dapat berupa sarana dan prasarana maupun pelatihan-pelatihan untuk menunjang sumber daya manusia yang ada yang terkait dengan kemajuan program.Bantuan pelatihan yang didapatkan seperti pelatihan kerajinan, pemasaran, pengolahan sampah oleh pihak Indocement.

Selain pelatihan yang diberikan tapi juga diberikan bantuan sarana prasarana serta fasilitas yang menunjang. Fasilitas ini berupa tempat pengelolaan sampah (TPS) pada bulan mei-juni 2013 yang difungsikan sebagai tempat untuk menampung sampah. Fasilitas sekre/perpustakaan lingkungan pada bulan februari 2014.Bantuan fasilitas transpotrasi juga diberikan yaitu motor bak terbuka yang mampu untuk mengambil sampah ke setiap rumahrumah warga. Bantuan transportasi datang pada bulan september 2013.Bantuan-bantuan yang diberikan melalui proses diskusi bersama.

\section{Tahapan Evaluasi dan Hasil Perubahan}

Evaluasi yang dilakukan suatu pengawasan dan penilaian oleh petugas dan kelompok pengelolaan sampah. Menurut Suharto (2009) menuliskan bahwa jika pemeliharaan tidak dilakukan maka tidak akan diketahui kelemahan, kekuatan, kebutuhan yang diperlukan hingga efektivitas dan efisiensinya tercapai jika program ini masih ingin terus dilanjutkan sehingga diperlukan evaluasi.

Petugas melakukan evaluasi dari data fisik dan non fisik yang didapatkan dari hasil pengawasan. Melalui data fisik dan non fisik ini petugas dapat memberikan penilaian. Didalam proses evaluasi dari tolak ukur yang sebelumnya telah di tetapkandidapat 5 tercapai 2 belum tercapai. Sehingga dapat disimpulkan program bank sampah kini dapat dikatakan berhasil walaupun belum memuaskan. Hal ini juga didukung oleh hasil exit programe menurut data yang didapat oleh petugas.

Prestasi juga menjadi pendorong kemajuan dengan diraihnya juara 2 didalam aplikasi program kampung iklim dan juga sudah banyak dikunjungi oleh pihak-pihak yang ingin mengetahui dan belajar terhadap proses pengelolaan sampah yang ada di Desa Cupang. Perubahan perilaku masyarakat. Dampak dari program bank sampah kini masyarakat semakin inisiatif didalam pengumpulan sampah.Jadi program ini sudah tercapai tujuannya atau dikatakan berhasil.

Tetapi juga ditemukan hambatanhambatan. Hambatan pertama yaitu keterbatasannya ilmu dan pengetahuan masyarakat terkait sampah. Kedua adalah penyebaran informasi terhadap adanya program bank sampah kepada masyarakat belum merata dan informasi soal harga sampah yang terlambat. Hambatan selanjutnya adalah masalah sumber daya manusia.

\section{Tahapan Terminasi}

Pertemuan awal antara kelompok pengelolaan sampah dengan pihak Indocement sekitar seminggu sekali atau kadang sebulan dua kali. Tetapi sekarang sudah semakin jarang berkisar 1 bulan sekali atau bahkan 2 bulan sekali. Komunikasi yang sudah semakin jarang adanya oleh petugas begitu juga dengan bantuan-bantuan yang semakin jarang. Dikatakan bahwa pada masa sekarang program bank sampah sedang menuju kearah kemandirian. Sehingga memang belum serta merta dilepas, walaupun programnya sudah selesai. Petugas terus melakukan monitoring untuk memastikan keberlanjutan program. 


\section{KESIMPULAN}

Berdasarkan pada hasil penelitian dan pembahasan yang telah diuraikan sebelumya, mengenai proses community development pada program bank sampah di Desa Cupang diperoleh kesimpulan sebagai berikut:

\section{Tahapan Engagement}

Pada tahapan ini, petugas telah menentukan lokasi wilayah dan sasaran program sebelumnya dilakukan dengan observasi langsung dan interaksi kepada masyarakat. Hal ini tidak terlepas dari masalah dan potensi yang dilihat sebelumnya. Kontak awal yang dilakukan dengan musyawarah untuk melihat ketertarikan dan kesediaan masyarakat untuk menjalani program. Proses ini berjalan dengan baik dengan timbulnya ketertarikan dan minat masyarakat akan adanya program.

\section{Tahapan Assessment}

Pada tahapan ini pelibatan langsung masyarakat didalam proses musyawarah dan diskusi didalam mengidentifikasi masalah, kebutuhan dan potensi melalui wadah BILIKOM yang melibatkan peran serta masyarakat didalam mencari solusi permasalahannya.Proses ini berjalan dengan baik dengan terbentuknya kelompok pengelolaan sampah mandiri ramah lingkungan Al-Karimah hasil dari penilaian akan kebutuhan bersama masyarakat dengan peran petugas sebagai pendamping..

\section{Tahapan Perencanaan Program}

Perencanaan dilakukan dengan menggunakan metode musyawarah yaitu merupakan proses perencanaan kegiatan program bank sampah. Kegiatan-kegiatan yang dirasakan perlu dilakukan seperti peningkatan kapabilitas SDM didalam pengelolaan sampah, penyebaran informasi dan penyadaran untuk melancarkan kegiatan pengelolaan sampah. Perencanaan ini juga membahas terkait tahapan pengelolaan sampah adanya dari mulai pengambilan hingga pengolahan (penjualan, pendaur ulangan dan pemanfaatan) sampah.Proses ini berjalan dengan baik disini masyarakat secara partisipastif didalam musyawarah untuk menentukan apa yang akan mereka pilih.

4. Tahapan Pemformulasian rencana aksi.

Tahapan ini adalah menentukan skala prioritas dari kegiatan-kegiatan yang dilakukan didalam proses pengembangan masyarakat disini. Tetapi didalam pengembangan masyarakat ini, tidak adanya skala prioritas yang digunakan tetapi lebih kepada masalah, kebutuhan dan waktu yang tersedia melakukan kegiatan. Proses ini dikatakan tidak begitu berjalan namun tetap disesuaikan dengan hasil assessment.Tahapan ini juga dilakukan pembuatan proposal baik oleh petugas awalnya dan kini oleh kelompok pengelola sampah.

\section{Tahapan Implementasi}

Tahapan implementasi dimulai dari kelompok pengolahan sampah berdiri serta pembuat perencanaan atau pada saat pelatihan. Proses ini sudah baik sesuai dengan apa yang direncanakan.

Pengolahan sampah itu sendiri ada 3 jenis pengolahan. Pertama sampah untuk dijual, sampah untuk didayagunakan kembali, dan sampah untuk biopori. Didalam proses pendayagunaan kembali tidak terlalu memberikan dampak ekonomis diakibatkan sistem pemasaran yang kurang.

Pelaksanaan kegiatan pengolahan sampah ini juga dimulai dari pengambilan sampah oleh kelompok pengolahan sampah sampai penjualan kepada pengepul, pendayagunaan menjadi kerajinan serta dimasukan kedalam biopori walaupun biopori kedepannya tidak berfungsi kembali.Program bank sampah didalam perkembangnnya terus mengalami kenaikan hingga dikatakan kegiatan-kegiatan penyebaran informasi dan penyadaran masyarakat berhasil 
adanya, serta kelompok pengolahan sampah juga sudah memiliki kemampuan pengolahan sampah yang baik sehingga juga dikatakan bahwa kegiatan peningkatan kapabilitas SDM sudah baik. Namun, sumber daya manusia (SDM) semakin menurun selama pelaksanaan berlangsung dari semula berjumlah 30 menjadi hanya 6 orang yang aktif.

Pendampingan dilakukan dimulai dari pembentukan kelompok hingga pelaksanaan. Petugas juga melakukan pengawasan sejak awal program disosialisasikan hingga pelaksanaan dilakukan.

Pengalokasian dana yang didapatkan dari hasil pemformulasian rencana tindakan (proposal) yg ini didapatkan dari penyokong dana (Indocement) didalam kelancaran program.

\section{Tahapan Evaluasi dan Hasil perubahan}

Evaluasi yang dilakukan adalah dengan melakukan evaluasi fisik (lapangang) dan evaluasi non fisik (data laporan) oleh petugas. Evaluasi yang dilakukan dimulai dari sosialisasi dimulai hingga pelaksanaan berlangsung. Evaluasi umum yang dilakukan adalah dengan melihat dari tolak ukur keberhasilan yang dilakukan serta exit programe yaitu berupa data survey yang dilakukan petugas terkait kinerja program bank sampah.

Selain itu, terlihat kekurangan terhadap pada proses penggalian kebutuhan peningkatan kapasitas kelompok terutama pada kemampuan menajemen organisasi dalam pengelolaan sampah dari perencanaan hingga evaluasi secara mandiri dan kemampuan memasarkan produk khususnya produk kerajinan. Walaupun demikian secara keseluruhan proses kegiatan ini sudah berjalan dengan baik. Hasil perubahanpun terjadi baik terhadap perubahan perilaku dan perubahan lingkungan yang didapatkan. Prestasi dan penghargaan pun didapatkan pada program kampung iklim. Sehingga evaluasi program inidapat menjadi bahan perbaikan setiap kegiatannya.

\section{Tahapan Terminasi}

Tahapan ini belum dikatakan selesai masih didalam proses pemandirian, dimulai dari kontak yang semakin jarang dilakukan oleh petugas serta bantuan-bantuan yang berkurang dari penyokong dana..

\section{SARAN}

Berdasarkan hasil penelitian dan pembahasan mengenai proses community development program kampung iklim di Desa Cupang Kecamatan Gempol Kabupaten Cirebon. Kegiatan pengembangan masyarakat dalam pengelolan sampah ini sudah dikatakan cukup baik meskipun hambatan banyak datang dari internal maupun eksternal. Hambatanhambatan yang muncul diantaranya adalah Pertama pada tahapan engagement dengan ketiadaan kontrak yang dibuat membuat petugas sulit didalam pengoptimalan program.

Hambatan kedua dengan tidak adanya kemampuan keorganisasian yang cukup baik dari kelompok pengelolaan sampah mengakibatkan, hambatan muncul pada tahap implementasi dengan kinerja yang sulit berkembang, hambatan ketiga pada saat pemandirian atau menuju tahapan terminasi, kelompok pengelolaan sampah disini mereka kerap kesulitan didalam menyelesaikan permasalahan yang timbul dikarenakan belum memilki kemampuan didalam menyusun suatu penyelesaian masalah dari mulai assessment sampai evaluasi secara mandiri.

Oleh karena itu peneliti menyarankan kegiatan berupa program Workshop "Manajemen kelompok pengelolaan sampah" yang tujuannya Peserta pelatihan diharapkan dapat memahami dan memiliki keterampilan mengenai manajemen tersebut secara konseptual dan teoritis, mampu mengelola suatu organisasi 
dengan baik dengan pelatihan manajemen yang diberikan, dan terbantu dengan adanya pendampingan langsung ketika terdapat permasalahan organisasi.Untuk keberlanjutan kegiatan adanya

Hal diatas karena pada tahapan evaluasi yang dilakukan petugas kurangnya proses penggalian kebutuhan terutama terkait kemampuan manajemen kelompok mengakibatkan pengelolaan kelompok yang kurang baik dan kesadaran yang kurang dianggotanya. Kesimpang siuran identitas kelompok yang tidak aktif juga memberikan dampak terhadap kinerja karena kelompok yang baik adalah kelompok yang memiliki jumlah dan identitas kelompok yang pasti. Sehingga kemampuan pengelolaan kelompok yang baik agar kedepannya mampu menyelesaikan permasalahan baik pada pelaksanaan program maupun ke organisasian untuk keberlanjutan program.

\section{DAFTAR PUSTAKA}

$\underline{B u k u}$

Maleong, Lexy J.2010. Metode Penelitian Kualitatif : Edisi revisi. Pt. Remaja Rosdakarya, Bandung.

Soehartono, Irawan. Metode Penelitian Sosial. Remaja Rosdakarya.2011.Bandung

Untung, Hendri B.2008. Corporate Social Responbility.Sinar Grafika..Jakarta

Suharto, Edi. 2006. Membangun MasyarkaatMemberdayakan Masyarakat.Reflika Aditama.Bandung

Suharto, Edi. 2008. CSR \& COMDEV Investarsi Perusahaan di Era Globalisasi.Alfabeta.Bandung

Suharto, Edi. 2007. Pekerja Sosial di Dunia Industri memperkuatan tanggungjawab sosial perusahaan (corporate social responbility).Refika Aditama.Bandung

Suharto, Ign. 2010.Program Pengembangan Masyarakat dan Peningkatan Kesejahteraan. Unpad Press

Isbandi. 2010. Pemberdayaan, Pengembangan Masyarakat, dan Intervensi Komunitas: Pengantar Pada Pemikiran dan Pendekatan Praktisi. Lembaga Penerbit Fakultas Ekonomi Universitas Padjajara. Jakarta.

Isbandi. 2012. Intervensi Komunitas \& Pengembangan Masyarakat: Sebagai Upaya Pemberdayaan Masyarakat. Jakarta: PT.Raja Grafindo Persada

Jim Ife. 2008. Community Development: Alternatif Pengembangan Masyarakat di Era Globalisasi. Yogyakarta: Pustaka Pelajar

Wibhawa, B.T Raharjo \& M.Budiarti. 2010. Dasar-Dasar Pekerjaan Sosial. Bandung: Widya Padjajaran

Suharto, Edi. 1997. Pembangunan, Kebijakan Sosial, \& Pekerjaan Sosial. Bandung: LSP-STKS Bandung

Mardikanto \& Soebianto, 2013. Pemberdayaan Masyarakat: Dalam Perspektif Kebijakan Publik. Bandung: Alfabeta, Edisi Revisi

Isbandi. 2012. Intervensi Komunitas \& Pengembangan Masyarakat: Sebagai Upaya Pemberdayaan Masyarakat. Jakarta: PT.Raja Grafindo Persada

M.Anwas, 2014. Pemberdayaan Masyarakat Di Era Global. Bandung: Alfabeta

Hikmat, Harry. 2013. Strategi Pemberdayaan Masyarakat. Bandung: Humaniora Utama Press, Edisi Revisi

Burhan Bungin, 2007. Penelitian Kualitatif: Komunikasi, Ekonomi, Kebijakan 
Publik, dan Ilmu sosial lainnya. Jakarta: Kencana. Edisi Kedua

Huraerah, Abu. 2008. Pengorganisasian dan Pengembangan Masyarakat: Model dan Strategi Pembangunan Berbasis Kerakyatan. Bandung: Humaniora

Theresia, Aprilia Dkk. 2015. Pembangunan Berbasis Masyarakat. Bandung : Alfabeta

$\underline{\text { Karya Ilimiah : Jurnal/Skripsi/Tesis }}$

Kamilah, E. 2014. Pemberdayaan Pengarajin Batik (Studi Kasus Program Pembinaan Usaha Mikro Kecil dan Menengah Pengrajin Batik Tulis Ciwaringin oleh CSR PT.Indocement Tunggal Perkasa Palimanan di Desa Ciwaringin, Kecamatan Ciwaringin, Kabupaten Cirebon, Jawa Barat).Skripsi. Fakultas Ilmu Sosial dan Ilmu Politik. Universitas Padjajaran

Putra, L.S. 2014. Proses Community Development Oleh Yayasan Insan Multi Mandiri Dalam Pengelolaan Sampah Di Perumahan Griya Taman Lestari Gudang Tanjungsari Sumedang. Skirpsi. Fakultas Ilmu Sosial dan Ilmu Politik. Univerisitas Padjajaran.

Jurnal : Pengelolaan Sampah Mandiri Ramah Lingkungan Skala Rumah Tangga Studi Kasus Desa Cupang

Sumber Lainnya:

Arsip CSR Indocement : Program Unggulan Pemberdayaan Masyarakat (SDP) Pengelola Sampah Ramah Lingkungan Kelompok Al-Karimah Desa Cupang
Profil Desa Cupang Tahun 2016

Kementrian Lingkungan Hidup Tahun 2012 : Proklim Sebagai Penguat Inisiatif Pengelolaan SDH Berbasis Masyarakat

PP No 18 Tahun 2012 yaitu pengelolaan sampah rumah tangga dan sampah sejenis sampah rumah tangga

Peraturan Menteri Lingkungan Hidup Nomor 19 Tahun 2012 tentang Program Kampung Iklim

PT. Indocement Tunggal Prakarsa. 2012. Laporan Keberlanjutan 2012 Suistanably Report

PT. Indocement Tunggal Prakarsa.2013. Laporan Keberlanjutan 2013 Suistanably Report

Raharjo, ST. 2015. Assessment untuk Praktik Pekerjaan Sosial dan Kesejahteraan Sosial. Bandung: Unpad Press 2015. Dasar Pengetahuan Pekerjaan Sosial. Bandung: Unpad Press. 2015. Keterampilan Pekerjaan Sosial: Dasar-dasar. Bandung, Unpad Press.

"Sampah di Indonesia Mencapai 1 Juta Meter perkubik" www.tempo.co.com diakses pada $20 / 03 / 2016$ 